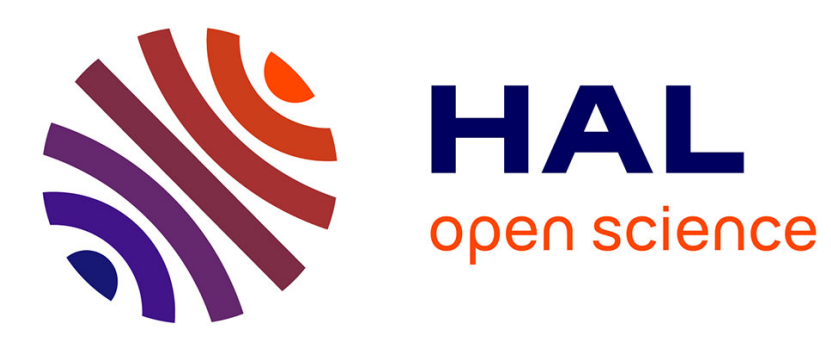

\title{
Increase in soil erosion after agricultural intensification: evidence from a lowland basin in France
}

\author{
Anthony Foucher, Sébastien Salvador-Blanes, O. Evrard, Anaëlle Simonneau, \\ Emmanuel Chapron, Thierry Courp, Olivier Cerdan, Irène Lefèvre, Hans \\ Adriaensen, François Lecompte, et al.
}

\section{To cite this version:}

Anthony Foucher, Sébastien Salvador-Blanes, O. Evrard, Anaëlle Simonneau, Emmanuel Chapron, et al. Increase in soil erosion after agricultural intensification: evidence from a lowland basin in France. Anthropocene, 2014, 7, pp.30-41. 10.1016/j.ancene.2015.02.001 . insu-01118118

\section{HAL Id: insu-01118118 https://hal-insu.archives-ouvertes.fr/insu-01118118}

Submitted on 18 Feb 2015

HAL is a multi-disciplinary open access archive for the deposit and dissemination of scientific research documents, whether they are published or not. The documents may come from teaching and research institutions in France or abroad, or from public or private research centers.
L'archive ouverte pluridisciplinaire $\mathbf{H A L}$, est destinée au dépôt et à la diffusion de documents scientifiques de niveau recherche, publiés ou non, émanant des établissements d'enseignement et de recherche français ou étrangers, des laboratoires publics ou privés. 


\section{Accepted Manuscript}

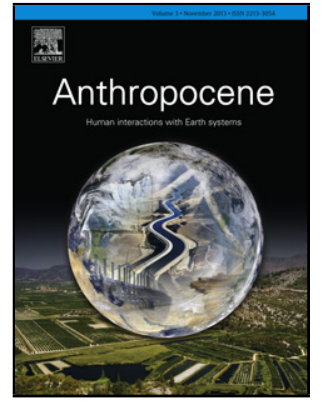

Title: Increase in soil erosion after agricultural intensification: evidence from a lowland basin in France

Author: Anthony Foucher Sébastien Salvador-Blanes livier Evrard Anaëlle Simonneau Emmanuel Chapron Thierry Courp Olivier Cerdan Irène Lefèvre Hans Adriaensen François Lecompte Marc Desmet

PII:

DOI:

Reference:

To appear in:

Received date:

Revised date:

Accepted date:
S2213-3054(15)00003-X http://dx.doi.org/doi:10.1016/j.ancene.2015.02.001

Please cite this article as: Anthony FoucherSébastien Salvador-Blaneslivier EvrardAnaëlle SimonneauEmmanuel ChapronThierry CourpOlivier CerdanIrène LefèvreHans AdriaensenFrançois LecompteMarc Desmet Increase in soil erosion after agricultural intensification: evidence from a lowland basin in France (2015), http://dx.doi.org/10.1016/j.ancene.2015.02.001

This is a PDF file of an unedited manuscript that has been accepted for publication. As a service to our customers we are providing this early version of the manuscript. The manuscript will undergo copyediting, typesetting, and review of the resulting proof before it is published in its final form. Please note that during the production process errors may be discovered which could affect the content, and all legal disclaimers that apply to the journal pertain. 
Increase in soil erosion after agricultural intensification: evidence from a lowland basin in France

Anthony Foucher, ${ }^{1}$ Sébastien Salvador-Blanes, ${ }^{1}$ Olivier Evrard, ${ }^{2}$ Anaëlle Simonneau, ${ }^{3,4}$ Emmanuel Chapron, ${ }^{4,3}$ Thierry Courp, ${ }^{5}$ Olivier Cerdan, ${ }^{6}$ Irène Lefèvre, ${ }^{2}$ Hans Adriaensen, ${ }^{7}$ François Lecompte, ${ }^{7}$ Marc Desmet, ${ }^{1}$

(1) E.A. 6293 GéHCO, GéoHydrosystèmes COntinentaux, Université F. Rabelais de Tours, Faculté des Sciences et Techniques, Parc de Grandmont, 37200 Tours, France

(2) Laboratoire des Sciences du Climat et de l'Environnement (LSCE/IPSL), UMR 8212 (CEA-CNRSUVSQ), Avenue de la Terrasse, 91198, Gif-sur-Yvette, France

(3) GEODE, UMR 5602 CNRS/Université de Toulouse 2, Allée A. Machado, 31058 Toulouse Cedex, France

(4) ISTO, UMR 7327 CNRS; Université d'Orléans, 1A rue de la Férollerie, 45071 Orléans Cedex 2, France

(5) Laboratoire CEFREM, UMR5110, Université de Perpignan via Domitia, 52 Avenue Paul Alduy, 66860 Perpignan Cedex, France

(6) Département Risques et Prévention, Bureau de Recherches Géologiques et Minières, 3 avenue Claude Guillemin, 45060 Orléans, France

(7) Plateforme CIRE, service d'imagerie, UMR PRC, Centre INRA Val de Loire, France

Corresponding author: Anthony.foucher@univ-tours.fr; Tel: (33) 247367090 


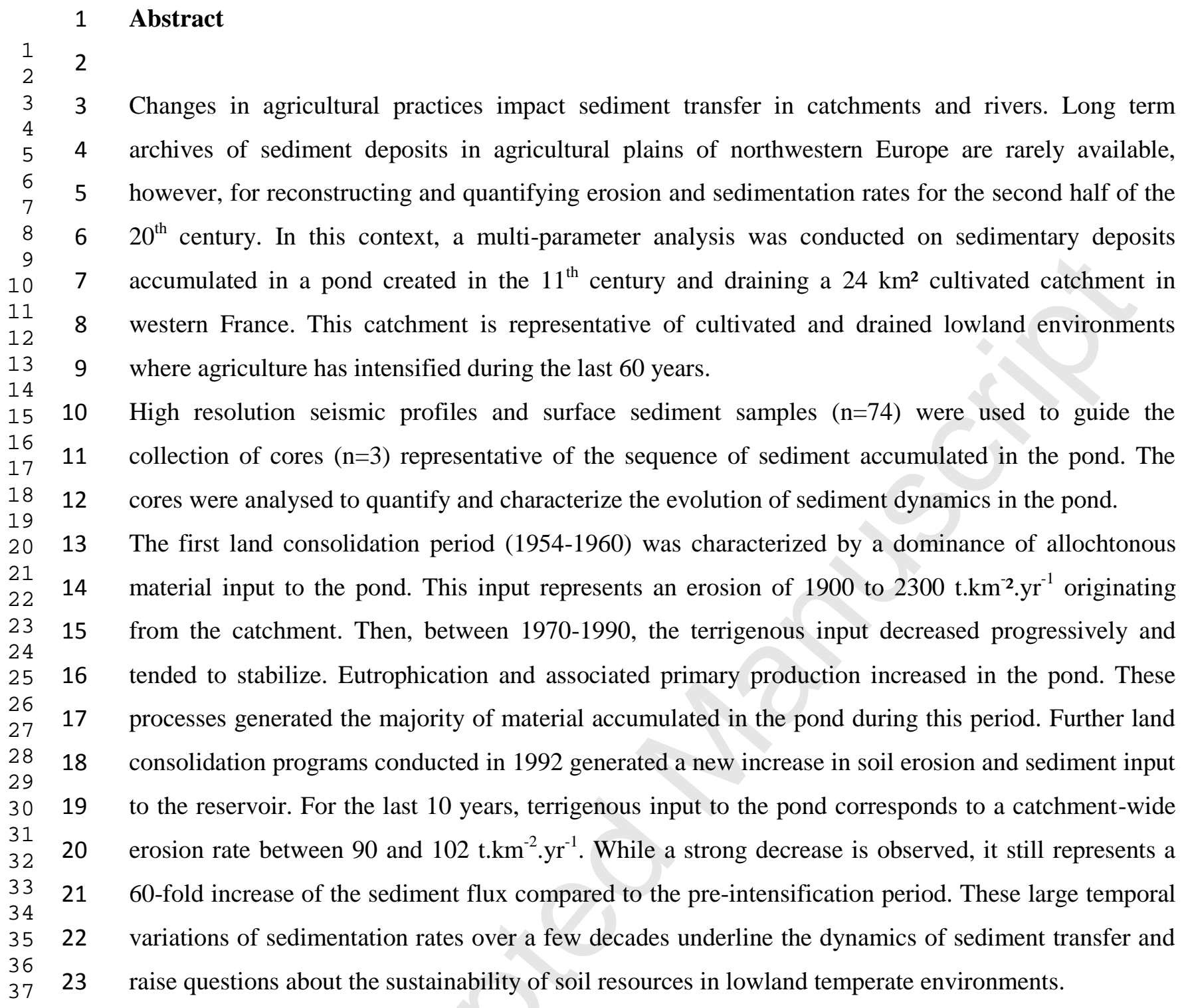

Keywords: land use change, agricultural catchment, lowland, sediment yields, pond sediments 


\section{Introduction}

Soil erosion has been identified by the European Commission as one of the most important factors of environmental degradation (Jones et al., 2012). Human activities and the intensification of agricultural practices in Western Europe have induced a significant acceleration of soil erosion during the second half of the $20^{\text {th }}$ century. Land management, as consolidation operations, hedge removals, stream resizing and the implementation of drainage networks have increased runoff and sediment connectivity between eroding hillslopes and the hydrosystems (Evrard et al., 2007). This higher connectivity between sediment sources and the rivers has facilitated the transfer of fine particles to aquatic environments. A continuous supply of fine particles to ponds and reservoirs contributes to their filling and modification of ecological niches (Kiffney and Bull, 2000; Waters, 1995). Fine particles were also shown to be very efficient in transporting organic, radioactive and metallic pollutants to and within hydrosystems (Ayrault et al., 2014; Chartin et al., 2013; Desmet et al., 2012).

For Europe, Cerdan et al. (2010) compiled existing data at the plot scale and estimated the mean sheet and rill erosion rates on arable land to be $360 t \cdot \mathrm{km}^{-2} \cdot \mathrm{yr}^{-1}$. However, there is a lack of knowledge regarding the fate and export of sediment towards lowland drained areas (Vanmaercke et al., 2011). Very little research exists on transfers of sediment for water bodies in small catchments $\left(<100 \mathrm{~km}^{2}\right)$ exposed to Atlantic climate conditions in Western Europe. In these basins, the connectivity between hillslopes and rivers is often high and they are therefore considered as privileged areas for the export of eroded material. However, very few data are available to quantify the specific sediment production of lowland drained areas. In the absence of long term measurement of water quality and suspended sediment dynamics in drained environments, sediment deposits provide a promising tool to reconstruct the effect of land use change on sediment yields and soil erosion over the last decades. Lake and reservoir deposits have been widely used in contrasted topographic/climatic settings to investigate the link between human activity, soil erosion and sediment production, generally over long timescales (ranging between $10^{\wedge^{2}}$ to $10^{\wedge^{3}}$ yrs), (e.g Macaire et al., 1997; Macaire et al., 2010; Massa et al., 2012). In agricultural regions, most investigations were realised on downstream floodplain deposits, and few studies focused on sediment accumulation in upstream reservoirs/ponds. For instance, Foster et al. (2003) and Foster and Walling (1994) analysed reservoir deposits to establish the link between land use change and sediment production in a small catchment characterized by a rolling topography. Dearing and Jones (2003) demonstrated an acceleration of sediment delivery during the 1950-1960 period in this small grazing catchment and attributed this increase to land use change. To our knowledge, the temporal evolution of sediment dynamics has not been reconstructed for lowland cultivated catchments. Existing studies are generally restricted to short time periods. Verstraeten and Poesen (2002) proposed for instance a methodology to quantify the export of material from small 
agricultural catchments in Belgium, by using the sediment records of 21 flood retention ponds, but their records are limited to a few years.

The lack of information on the evolution of sediment/erosion dynamics for lowland drained catchments is therefore mainly explained by the difficulty to find an old sedimentary reservoir characterized by a high sedimentation rate as to reconstruct the link between land use change, soil erosion and sediment production. In this context, the characteristics of sediment deposits accumulated in a pond draining a $24 \mathrm{~km}^{2}$ cultivated catchment of central France have been investigated. The study area has been selected as it is representative of the agricultural drained plains of Western Europe. An original multi-parameter approach was conducted in order to reconstruct the evolution of sediment dynamics as a result of land use changes during the second half of the $20^{\text {th }}$ century.

\section{Materials and methods}

\subsection{Study site}

The Louroux pond drains a small agricultural lowland catchment $\left(24 \mathrm{~km}^{2}\right)$ located in the south-western edge of the Parisian basin (France), in the Loire Valley (Fig. 1a). It is characterized by smooth topography (mean slope of $0.44 \%$ ) with an altitude ranging between 99 and $127 \mathrm{~m}$. (Fig. 1c). Six different lithologies are found in the catchment: Senonian flint clays (23\%), Ludian lacustrine limestone (6\%), Eocene siliceous conglomerate (1.4\%), Helvetian shelly sands (18\%), post-Helvetian continental sands and gravels (32\%) and Quaternary loess (18\%). Soils are mostly hydromorphic and prone to crusting. They are classified as Epistagnic Luvic Cambisols (Froger et al., 1994; Rasplus et al., 1982). The area is dominated by an Atlantic climate with a mean annual rainfall of $684 \mathrm{~mm}$ (between 1971-2000).

For more than 50 years, the Louroux catchment - as the large majority of agricultural plains in Western Europe - has been affected by intense modifications of land use and agricultural practices (Antrop, 2005). Before World War II, the Louroux catchment was a large wetland with hedgerows, and it was mainly dedicated to crop-livestock farming. Cereal production was only possible in a small part of the catchment because of unfit soil moisture conditions. After the war, agriculture modernization sought to evacuate the water in excess from the soils to allow for intensive cereal farming. The hedges have been progressively removed, and land has been reallocated on three occasions (first in 1935 and then in 1955 and 1992). Woodlands and grasslands are now marginal in the catchment (covering respectively 17 and 7\% of the total catchment surface) (I\&CLC2000, 2002). Streams have been created or re-sized (Foucher et al., submitted) to facilitate the evacuation of water from the hillslopes. Between 50 to $90 \%$ of the catchment surface has been drained. As much as 220 tile drain outlets have been identified across the entire catchment. 
The Louroux pond (52 ha) was created in the $10^{\text {th }}$ or $11^{\text {th }}$ century (Fig. 1b). Water and sediment are supplied to the pond by five main tributaries that drain the catchment hillslopes. Overflow of the pond only occurs during high water levels in winter. This situation leads to massive deposition of fine particles in the pond during most of the year. A second pond (i.e., Beaulieu pond (3 ha)) was dug out in the $18^{\text {th }}$ century to the west of the Louroux pond. Both reservoirs are directly connected. Nowadays, the Beaulieu pond is almost entirely filled with sediment (Fig. 1b). The Louroux pond has been drained on two occasions during the last 15 years (i.e., between 2001-2003 and in 2012-2013 for one year). An aerial LiDAR survey conducted in early spring of 2013 (i.e. during the last drainage period of the pond), underlines the very shallow character of the Louroux pond, with an average depth of $2 \mathrm{~m}$, and a maximum depth of $4.8 \mathrm{~m}$ right in front of the dam (Fig. 2a).

\subsection{Seismic survey}

A high resolution seismic survey was conducted during summer of 2012 across the Louroux pond. In total, $7.5 \mathrm{~km}$-long high resolution seismic profiles were collected (Fig. 2c) from an inflatable boat (Limnoraft). These analyses provide a overall picture of the sediment deposits, and allows to quantify the volume of sediment accumulated in the pond (Chapron et al., 2007; Twichell et al., 2005). Seismic profiles were collected with a parametric echo-sounder INNOMAR SES-2000 Compact $^{\circledR}$. The INNOMAR sonar is adapted to shallow water environments. The maximum theoretical resolution is 6 $\mathrm{cm}$ with a wavelength that can vary between 5 and $15 \mathrm{kHz}$. The wave speed in the water was defined at $1500 \mathrm{~m} / \mathrm{s}$. Positions were recorded with a GPS device coupled with the seismic acquisition system. Acoustic facies were correlated with observations made on the sediment cores.

\subsection{Sediment sampling}

\section{Surface sediment}

Surface sediment samples were collected during summer 2012. Based on the analyses made on these samples, spatial variation of sediment characteristics derived from surface sediment samples, was extrapolated to the entire pond. The samples were collected using a floating platform (quadriraft) and a short gravitational corer UWITEC of $90 \mathrm{~mm} \emptyset$. In total, 74 surface samples (top $0-5 \mathrm{~cm}$ corresponding to the most recent deposits) were collected following a random location sampling technique (Fig. 2b).

\section{Sediment cores}

Three sediment cores, with respective lengths of 42,71 and $112 \mathrm{~cm}$, were collected during two surveys conducted in 2012 using a floating platform and a corer UWITEC of $63 \mathrm{~mm}$ (cores Lrx12-01 and Lrx12-02) and in 2013 with an UWITEC corer of $90 \mathrm{~mm} \emptyset$ (core Lrx13-01). The cores were 
collected in different parts of the pond to document the potential variations of sediment dynamics across the reservoir (Fig. 2a).

\subsection{Sediment analyses}

The cores have been cut in length with a bank equipped with a circular Dremel ${ }^{\circledR}$ saw. The cores and the surface samples were submitted to the same set of analyses in order to correlate the cores and to determine the overall physical and chemical properties of sediment deposits in the pond.

\section{Scanner imagery}

Computer Tomography (CT) images of the three cores were obtained by using the facilities (Siemens Somatom 128 Definition $\mathrm{AS}^{\circledR}$ scanner) of the CIRE platform (Surgery and Imaging for Research and Teaching; INRA Val de Loire). Images of the relative density of sediment were generated, with the lighter shades corresponding to denser sediment (Sufian and Russell, 2013). The dry bulk density $\left(\mathrm{g} . \mathrm{cm}^{-3}\right)$ was also measured at a centimetric scale on each of the three cores.

\section{Spectrocolorimetry}

The spectrocolorimetric properties of the core and surface sediment samples were recorded with a Minolta $2600 \mathrm{D}^{\circledR}$ spectrocolorimeter. These values provided an overview of the sediment content by measuring wavelengths ranging between 400 and $700 \mathrm{~nm}$ (Debret et al., 2011; Rein and Sirocko, 2002).

\section{Grain size}

Destructive analyses were performed with a laser Malvern Mastersizer ${ }^{\circledR}$ grain sizer, to define the particle size distribution (between $0.01-3500 \mu \mathrm{m}$ ). Grain size analyses were conducted on the surface sediment samples and in the three cores, with a centimetric resolution.

\section{Palynofacies}

Analyses of quantitative organic petrography were carried out on eight samples selected along the LrX-1301

Core, according to the lithological units identified. These analyses consist of an optical identification of the non-pollen organic components present in a constant volume of sediment $\left(1 \mathrm{~cm}^{3}\right)$, after removal of the silicate and carbonated phases by hydrochloric and hydrofluoric treatments, respectively. The non-pollen palynomorphs are characterized by their optical properties (colour and reflectance), their forms (amorphous or figurative) and their origins (algal, phytoclastic or fossil, Tyson, (1995)). This approach is frequently used to discriminate the proportions of autochtonous and allochtonous organic material in lacustrine sediments (Jacob et al., 2004; Patience et al., 1996), and to characterize the trophic level of the lake through the identification of algae populations (Simonneau et al., 2013b), or to document the type of vegetation cover found in the drainage basin (Simonneau et al., 2013a). This 
method has recently been adapted to quantify the proportions of each family of organic material (for more details, see Graz et al. (2010), Simonneau et al. (2014; 2013b)) demonstrated that it is possible to quantify the contributions of allochtonous sediment fluxes originating from catchment erosion and the autochtonous fluxes produced in the lake itself based on these analyses.

\section{Organic matter}

Total organic carbon (TOC) and total carbonate (TC) contents were measured in surface sediment samples at the Laboratoire d'Analyses des Sols (INRA, Arras, France). TOC was measured by loss on ignition at $550^{\circ} \mathrm{C}$.

\section{Fallout radionuclides}

The Lrx13-01 core was cut into $3 \mathrm{~cm}$ increments for the uppermost $68 \mathrm{~cm}$, and then into $6 \mathrm{~cm}$ intervals to a depth of $110 \mathrm{~cm}$. Fallout radionuclide activities (caesium-137 $\left({ }^{137} \mathrm{Cs}\right)$ and lead-210 $\left.\left({ }^{210} \mathrm{~Pb}\right)\right)$ were measured in all samples by gamma spectrometry at $661.6 \mathrm{keV}$ and $46.5 \mathrm{keV}$ using the very low-background HPGe detectors available at LSCE (Gif-sur-Yvette, France). ${ }^{210} \mathrm{~Pb}_{\mathrm{xs}}$ activities were calculated by subtracting the supported activity from the total ${ }^{210} \mathrm{~Pb}$ activity (measured at 46.5 $\mathrm{keV}$ ) using two ${ }^{226} \mathrm{Ra}$ daughters, i.e. ${ }^{214} \mathrm{~Pb}$ (average count at 295.2 and $\left.351.9 \mathrm{keV}\right)$ and ${ }^{214} \mathrm{Bi}(609.3$ $\mathrm{keV})$. Fallout radionuclides are commonly used to date sediment that deposited during the last century in lacustrine environments (Benoit and Rozan, 2001). Peaks in ${ }^{137} \mathrm{Cs}$ activities may be attributed to two events: the maximal emissions are associated with atmospheric bomb testing (1963) and the Chernobyl accident (1986). In France, fallout of cesium due to Fukushima accident may be considered negligible $\left(\sim 2 \mathrm{~Bq} / \mathrm{m}^{2}\right)$ (Evrard et al., 2012). The ${ }^{210} \mathrm{~Pb}_{\mathrm{ex}}$ decay allows dating sediment deposits over a time scale of 100-150 years.

\subsection{Core dating and estimation of catchment-wide erosion rates}

Dating of the sequence of sediment deposits is based on fallout radionuclide measurements. To specify the age of the lower part of the Lrx13-01 core, ${ }^{14} \mathrm{C}$ measurements were conducted on 3 samples (root debris collected at 50 and $82 \mathrm{~cm}$, and in a layer containing leaves at $108 \mathrm{~cm} \mathrm{depth)} \mathrm{at} \mathrm{the}$ Beta Analytic Laboratory, Miami (USA) with an accelerator mass spectrometer (AMS). Radiocarbon data were calibrated on calendar date with the 'clam' R program (Blaauw, 2010; Reimer et al., 2013). The age depth model was constructed by combining all chronological information available along the core. These data points were compared to the continuous sedimentation curve obtained with the CIC model (Libby, 1967) based on Lead 210 excess activities. To reduce the effect of compaction on the estimates, the sedimentation rate was evaluated by converting the core depths (in $\mathrm{cm}$ ) into mass depths using the procedure described in Van Metre et al. (2004).

Erosion rates for the upstream catchment were calculated by dividing the mass of sediment accumulated in the pond $\left(\mathrm{t} . \mathrm{yr}^{-1}\right)$ by the catchment surface $\left(\mathrm{km}^{2}\right)$. The evolution of the sedimentation rate through time was evaluated by coupling seismic data with core dating. The total mass of sediment 
contained in each unit identified by the seismic survey was calculated using the average dry bulk density measured in the cores. Sedimentation rates were corrected for autochtonous material input, so that the catchment-wide erosion rates are based on the terrigenous material input only.

\section{Results and discussion}

\subsection{Seismic facies}

The compilation of seismic data clearly indicates the occurrence of a relatively homogenous sedimentation in the pond with a succession of sedimentary units across the entire pond surface (Fig. 3).

Seismic profiles P1, P2 and P3 (Fig. 3) are selected to illustrate the geometry of the sedimentary body in the pond. The total thickness of the sediment accumulation could not be evaluated with the seismic data as the seismic waves were rapidly absorbed due to the high sediment density. Below 50 to $95 \mathrm{~cm}$ depth, the penetration seismic signal was progressively attenuated. However, two high amplitude reflection zones were clearly identified in the upper part of the deposits. The first zone covers a mean depth of $38 \pm 7 \mathrm{~cm}$ across the pond. The distribution of this reflector was very homogeneous although some local fluctuations in sediment thickness were recorded. The second zone characterized by a mean thickness of $17 \pm 7 \mathrm{~cm}$ is found at $60 \mathrm{~cm}$ depth. The first sediment unit (hereafter referred to as seismic unit 1) characterized by a transparent acoustic facies and a draping geometry was mapped between both reflection zones.

\subsection{Characterization of surface sediment}

A map of the main depositional facies of the Louroux pond was drawn using a fuzzy k-means classification (Fig. 4). This classification was performed based on total organic carbon (TOC) and total carbonate (TC) data and the grain size composition of the sediment. This classification aimed to regroup similar samples in a predefined number of classes (i.e., 4 groups).

Class 1 (C1) is only found in the southeastern part of the pond (Fig. 4). Sediment of this unit is characterized by high TOC values (mean of $234 \mathrm{~g} \cdot \mathrm{kg}^{-1}$ ) and the highest TC values measured in the pond surface sediments (mean of $208 \mathrm{~g} \cdot \mathrm{kg}^{-1}$ ). Regarding particle size, C1-type sediment is dominated by a silty matrix (57\%) although it contains a significant sand proportion $(39 \%)$.

Class 2 (C2) is located in the northern part of the pond (Fig. 4). C2 sediment is characterized by the lowest TOC and TC contents (means of $120 \mathrm{~g} \cdot \mathrm{kg}^{-1}$ and $1.04 \mathrm{~g} \cdot \mathrm{kg}^{-1}$, respectively). Particle size is dominated by sands with coarse sands representing more than $30 \%$ of the grain size fraction. 
Class 3 (C3) is characteristic of sediment mainly originating from the left-bank tributaries. C3 material is associated with similar TOC contents as C1 sediment (mean of $220 \mathrm{~g}^{-\mathrm{kg}^{-1}}$ ), but has lower TC contents (mean of $25 \mathrm{~g} \cdot \mathrm{kg}^{-1}$ ). This class is dominated by a mix of silt $(50 \%)$ and sand (46\%).

Finally, C4 material is found in the central depression of the pond. Compared to the others classes, C4 sediment is characterized by intermediate TOC and TC contents (means of 200g. $\mathrm{kg}^{-1}$ and $122 \mathrm{~g} \cdot \mathrm{kg}^{-1}$, respectively) and is dominated by the fine-silt fraction (58\%).

$\mathrm{C} 1$ and C3 material is found close to the inlet of the main pond tributaries (Fig. 4), and displays similar characteristics but has different carbonate content. This likely reflects the different lithologies of the subcatchments, with a dominance of lacustrine limestones and shell sands in the $\mathrm{C} 1$ area (Rasplus et al., 1982) and the outcrop of a flint clay formation in the C3 zone (Froger et al., 1994). C4 material found in the central depression of the pond is supplied by a mix of sources derived from several tributaries.

\subsection{Core facies}

\section{Sediment composition}

Among the three cores, core Lrx13-01 likely provides the longest temporal records. The core was collected in the central pond depression unaffected by the dredging area, where $\mathrm{C} 4$ sediment accumulates (Fig. 4). The core structure was correlated with the acoustic facies derived from by seismic data.

Spectrocolorimetric parameters, particle size and material density are used to identify four different sedimentary units (U1 to U4, Fig. 5) along the entire sediment sequence.

On the top of the core, the first unit (U1, 0 to10 cm, Fig. 5) is characterized by a very low density compared to the scanner image obtained for the rest of the core. Quantitative organic petrographic analyses show that $\mathrm{U} 1$ sediment is essentially composed by autochthonous material. The algal fraction dominated by Pediastrum $S p$ fluctuates between 50 and 56\%. This first unit corresponds to seismic unit 1 described previously (i.e. 4.1). The thickness of this first unit does not exceed $10 \mathrm{~cm}$ in core Lrx13-01, whereas seismic data show a unit with thicknesses ranging from 2 to $79 \mathrm{~cm}$ across the core. This result illustrates the strong compaction that occurred during coring (Fig. 6).

As shown by the seismic survey, unit U1 is found across the entire surface of the pond. It corresponds to fine-grained sediment rich in water and characterized by a very low density. This sediment accumulated in the pond during the last 10 years (average density of $0.29{\mathrm{~g} . \mathrm{cm}^{-3}}^{-3}$ ). The draping geometry of unit U1 is characterized by homogenous depths. On acoustic profiles, this upper unit has an average thickness of $38 \pm 7 \mathrm{~cm}$.

A sediment thickness map of seismic unit 1 was generated by ordinary kriging based on the thicknesses derived from seismic profiles (Fig. 7). The corresponding volume of sediment - 
accumulated between 2003 and 2013 - was calculated. Sediment thickness estimations derived from the interpolation ranged between 2 and $74 \mathrm{~cm}$ (average value of $38 \pm 7 \mathrm{~cm}$ ). (fig-7).

A second unit, i.e. U2, is observed between 10 and $32 \mathrm{~cm}$ depth (Fig. 5). U2 is characterized by the presence of desiccation cracks observed during visual description of the core and on the scanner imagery (Fig. 5). These cracks may correspond to dense sediment embedded in a softer matrix of particles with properties comparable to those described in unit U1. During the last drainage of the pond in 2013, field observations showed that the fine sediments dried up and formed large desiccation cracks similar to the ones observed in the core, which confirms the relevance of this hypothesis. Unit $\mathrm{U} 2$ can be subdivided into two parts: a first sub-unit, located between 10 and $22 \mathrm{~cm}$ depth, containing macro-cracks characterized by a decrease in the organic matter content (wavelengths ranging between 605-695 nm), and a second sub-unit, located between 22 and $32 \mathrm{~cm}$, which does not display any desiccation feature. During the subsequent pond refill, cracks probably disappeared as they were filled with lower density sediments displaying U1 material characteristics.

Acoustic waves were quickly absorbed in seismic unit U2 and provided only information on the upper $17 \mathrm{~cm}$ layer of this unit. Interestingly, in core Lrx13-01, this layer corresponded to the zone where cracks were observed. This might have occurred during the period of pond water refilling after the drainage period (2001-2003).

The seismic survey therefore allows distinguishing a succession of two seismic units. A first unit corresponding to the post- 2003 sedimentation and a second unit, partially penetrated by the seismic waves corresponding to a pre-2003 sedimentation. This layer is more compacted and heterogeneous and it likely deposited during the last drainage period of the pond. U1 would therefore have accumulated after 2003.

Within the two upper core units (U1 and U2, Fig. 5), the fraction of autochthonous material becomes increasingly important. This increase in primary production might be due to an increase of fertilizer use and/or to the implementation of soil conservation measures on hillslopes. This increase of autochthonous production might alternatively have been triggered by a release of nutrients in the pond that would have triggered a fish mortality event.

Below $32 \mathrm{~cm}$ depth, a third unit is observed, characterized by a dramatic change in particle size properties and spectrocolorimetric parameters. It corresponds to a sharp decrease in organic material and dominance of allochtonous organic fraction in sediment (Fig. 8). Organic petrography data also showed the presence of a low and almost constant contribution of autochthonous production comprised between 9 and 13\%. In parallel, an important qualitative change in the algae content was observed. Spirogyra algae - reflecting good ecological conditions - dominate in the lower part of this unit $(67-110 \mathrm{~cm})$, while Pediastrum algae prevail between 32 and $45 \mathrm{~cm}$. The latter are typical of eutrophic environments, and this result shows therefore a progressive shift towards an eutrophication of the ecosystem $(47 \mathrm{~cm})$. Then, sediment of unit U3 remains very homogeneous down to $80 \mathrm{~cm}$ 
depth. The dry bulk density fluctuates locally, which may correspond to the occurrence of previous pond drainage periods of short duration that led to limited compaction of the sediment and not to the formation of sedimentary cracks. From $80 \mathrm{~cm}$ depth to the basis of the core, a fourth unit composed of an alternance of organic and clay layers of $2-5 \mathrm{~cm}$ thickness is observed. The organic layers containing vegetal and root debris might have deposited during drainage periods of the pond, but no historical archive is available to support this assumption. Organic petrography analyses of terrigenous layers show that they contained the highest proportion of allochthonous inputs, with 77 to $91 \%$ of the deposits originating from the catchment hillslopes. This last unit could therefore correspond to a period of major changes in the catchment.

\section{Correlation between sediment cores}

Correlation between cores Lrx12-01, Lrx12-02 and Lrx13-01 was done based on scanner imagery and spectrocolorimetric data. Location of unit U1 could be identified in the three cores (Fig. 5). This unit has a variable thickness $(6-16 \mathrm{~cm})$, but similar low densities and high organic contents. The difference of thickness in the three cores may be explained by local variations in sediment deposition rates and by a variable compaction from using different core sampling methods.

The lower limit of this unit (U1) corresponds to a sharp increase in density. This transition was previously described in core Lrx13-01, and it is also recorded in core Lrx12-01. In the latter core, large sedimentary cracks are also found in the denser sediment located between 16 and $26 \mathrm{~cm}$ depth. As for core Lrx13-01, they are filled with dense material that probably migrated from unit U1. In core Lrx1202, these cracks are not visible. Nevertheless, the upper limit of this second unit (U2) associated with a decrease in the organic matter content can be identified in the three cores. The lower limit of this unit corresponds to a global increase in the density. The lower limits of unit 3 are hardly visible in cores Lrx12-01 and Lrx12-02.

\subsection{Core chronology}

The construction of the age depth model for the core Lrx13-01 is mainly based on the identification of the last drainage period of the pond at $10 \mathrm{~cm}$ depth (2001 to 2003), on the record of the ${ }^{137} \mathrm{Cs}$ Chernobyl peak (1986) at $30 \mathrm{~cm}$ depth and on the record of the peak associated with maximum thermonuclear bomb fallout (1963) at $56 \mathrm{~cm}$ (Fig. 8). This age depth model is confirmed by the one deduced from ${ }^{210} \mathrm{~Pb}_{\mathrm{ex}}$ data (Fig. 8). The age depth model is therefore consistent in the first half of the core where both dating methods provide similar results.

Below $56 \mathrm{~cm}$ depth, the ${ }^{210} \mathrm{~Pb}_{\mathrm{ex}}$ profile has not been used for dating because of variations in ${ }^{210} \mathrm{~Pb}_{\mathrm{ex}}$ activities that likely reflect changes in sediment sources across the catchment. However, the presence of ${ }^{137} \mathrm{Cs}$ at the base of the core suggests that the entire sequence of deposits is recent and 
deposited after 1954 (Fig. 8). All dates derived from AMS ${ }^{14} \mathrm{C}$ data on the lower part of the core were rejected.

Organic petrography analyses indicate that the dominant terrigenous fraction at the basis of the core is essentially composed of mineral particles. The dominance of this fraction in U4 could be linked to the major anthropogenic changes that took place between 1945 and 1960. During this period, streams were created or modified, and land consolidation schemes were implemented on hillslopes between 1952 and 1956. These changes might have strongly accelerated erosion in the catchment and sediment supply to the pond. This section of the core can therefore correspond to sediment deposition between 1954 and the early 1960s.

Organic petrography analyses show a sharp change in the trophic state of the lake during the deposition of unit U3 located between 45 and $65 \mathrm{~cm}$ depth, with a change in the dominant algal type switching from Spirogyra to Pediastrum (Fig. 8). This transition corresponds to a strong eutrophication of the pond. Its occurrence was also documented in botanical surveys conducted in the Louroux pond between 1970-1980. During this period, land management changed in the catchment, with the extension of the drainage network and the creation of ditches although theses changes were probably of minor importance compared to land consolidation works implemented in the 1950s.

\subsection{Reconstruction of historical sediment yields}

Recent export of sediment

Between 2003-2013, 163,000 $\mathrm{m}^{3}$ of allochthonous and autochthonous material is estimated to have accumulated in the Louroux pond. This volume corresponds to an annual input of 4890 t.yr $^{-1}$ (dry bulk density $=0.3 \mathrm{~g} . \mathrm{cm}^{-3}$ ) across the 39 ha surface area of the pond. As we estimated that the proportion of autochthonous material ranged between 44 and $50 \%$ in Unit 1 (see section 4.3 for details), the quantity of material originating from the catchment hillslopes can be estimated between 2152 and 2445 t.yr $^{-1}$ for the entire Louroux pond during the 2003-2013 period. This value is probably underestimated, as a fraction of sediment (estimated to $<10 \%$ of the total catchment erosion) probably deposited in the upstream Beaulieu pond. The quantity of sediment accumulated can also be underestimated due to the overflow of the pond during part of the year. The trapping efficiency of this pond could not be calculated as detailed in previous studies (e.g Kummu et al., 2010; Verstraeten and Poesen, 2000) because data of suspended sediment inputs or outputs were not available for this site. Nevertheless, field observations suggest that the proportion of sediment exported downstream is very low $(<10 \%)$ and that the associated underestimation of sediment deposition is therefore negligible. 
Based on sedimentary accumulation in the Louroux pond, total erosion rates in the catchment combining soil surface, subsurface and channel bank erosion processes are estimated between 90 and $102 \mathrm{t} . \mathrm{km}^{-2} \cdot \mathrm{yr}^{-1}$. These results suggest that despite a flat topography, sediment exports to the pond are rather high although not exceptional. These values are similar to the median value of sediment yields measured in Europe (median $=92 \mathrm{t} \cdot \mathrm{km}^{-2} \cdot \mathrm{yr}^{-1}$ based on a dataset of $\sim 1800$ catchments (Vanmaercke et al., 2011)).

Anthropogenic impact on the Louroux catchment and long term evolution of flux

Erosion and sedimentation dynamics in the Louroux catchment since the end of the 1950s were reconstructed based on the analyses on core Lrx13-01 (Fig. 9). A sedimentary flux model was built based on the calculation of a mean sedimentary flux over time (SR), which allowed to estimate the quantity of sediment deposited $\left(\mathrm{t} . \mathrm{yr}^{-1}\right)$ between successively dated layers in the core (Fig. 9). This average flux was corrected for primary production in the pond. It reflects therefore the allochthonous input of material from the catchment in units U1 to U4.

No data were available to document the flux that prevailed before 1950. Nevertheless, if the current sediment rate is applied to the period between $1000 \mathrm{AD}$ and $1950 \mathrm{AD}$, thickness of the corresponding sediment accumulation would exceed $36 \mathrm{~m}$, which is impossible as the elevation difference between the base of the dam (substratum) and the coring site (Lrx13-01) reaches $5.1 \mathrm{~m}$ only. To our knowledge, dredging of the pond that could have modified the sediment thickness was not conducted during the 1000-1950 AD period. By subtracting the thickness of core Lrx13-01 to this amount, we can therefore hypothesize that a maximum average input of $40 \mathrm{t}^{\mathrm{yr}} \mathrm{r}^{-1}$ of material was supplied to the pond between 1000-1950 AD (by supposing a constant dry bulk density during this period like observed for the last 60 years). This suggests that the current sediment flux is at least 60 -fold higher than the flux observed during the previous millennium. A first increase in the flux, which could unfortunately not be recorded in core Lrx13-01, might have occurred in 1935 when the first land consolidation scheme was implemented in the catchment.

The anthropogenic pressure then strongly increased between 1945 and 1960 when the largest consolidation scheme took place. This period is partly recorded in unit U4 of core Lrx13-01. The palynofacies analyses showed that the largest terrigenous input recorded in the core occurred during

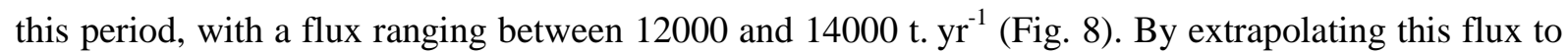
the material exported from the entire catchment and by assuming that the geometry of sediment deposits was similar to the one observed during the last 10 years, it is possible to estimate a material export rate from the hillslopes reaching $2100 \mathrm{t} . \mathrm{km}^{-2} \cdot \mathrm{yr}^{-1}$. This very high value comprises sediment supplied by soil surface erosion but also material eroded from the channel banks. This 15 -yr period is 
characterized by a general destabilization of the catchment, as the wetland has been transformed into an intensively cultivated catchment within a few years' time. Landscape destabilization similar to what is observed for the Louroux catchment was also documented for other parts of the world during the 1950-1960s. In the English Lake District, the rise in sedimentation rates was correlated to the increase in sheep grazing densities that accelerated soil erosion (van der Post et al., 1997). Similar trends were recorded in the Canadian Prairies (de Boer, 1997), in Japanese floodplains (Ahn et al., 2010) or in cropland areas of the American Midwest (Heathcote et al., 2013). In most of these studies, the input of material to the river network was shown to decrease slowly after this destabilization phase. This trend was also recorded in the Louroux Pond in response to a progressive slowdown of the extension of the tile drain and river networks in the catchment. Then, between the 1960s and 1980s, the allochthonous sedimentary input continued to decrease from 9000 t. $\mathrm{yr}^{-1}$ to $6700 \mathrm{t}^{\mathrm{yr}} \mathrm{r}^{-1}$. It is likely that after a period of large-scale changes in the catchment, the system progressively tend to stabilization. Soil erosion on hillslopes was estimated at $1100 \mathrm{t} \cdot \mathrm{km}^{-2} \cdot \mathrm{yr}^{-1}$ during this period (1960-1980). Simultaneously, the progressive eutrophication of the pond was observed. This phenomenon might be due to an increase of fertilizer use in the catchment and/or to an increase of sediment connectivity between the hillslopes and the pond. Between 1980 and 1990, the system was characterized by a major decrease of material input to the pond. The average deposition flux ranged between 2300 and 2800 t.yr $^{-1}$ during this period, which corresponds to a loss of material from the slopes of about $400 \mathrm{t} \cdot \mathrm{km}^{-2} \cdot \mathrm{yr}^{-1}$. A third land consolidation scheme was implemented during the second half of the 1990s. It led to a slow increase

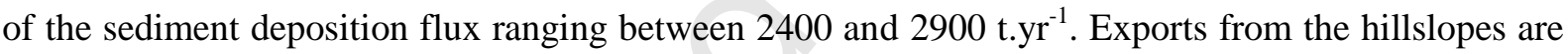
estimated to $425 \mathrm{t} . \mathrm{km}^{-2} \cdot \mathrm{yr}^{-1}$ during this period. Finally, during the last decade, a new decrease of the material flux to the pond was recorded, with a material input ranging between 1300 and 2100 t.yr ${ }^{-1}$.

Nowadays, erosion rates remain high and correspond to the lower limit of tolerable erosion rates according to Verheijen et al (2009). Moreover, although the terrigenous inputs to the pond have progressively decreased since the end of the 1980s, a massive increase of algal production is observed in the reservoir (Fig. 8) reflecting a general degradation of the water quality. The Louroux pond might be completely filled with sediment in 2100 (assuming that the reservoir traps all sediment and that the current sedimentation rates are maintained).

Erosion rates recorded at the outlet of the Louroux catchment $\left(90-102 \mathrm{t} . \mathrm{km}^{-2} \cdot \mathrm{yr}^{-1}\right)$ are of the same order of magnitude as sediment yields measured in agricultural catchments of similar size in Europe (60-260 t. $\left.\mathrm{km}^{-2} \cdot \mathrm{yr}^{-1}\right)$, (Cerdan et al., 2010; Vanmaercke et al., 2011), (Table 1). Climate and topography were widely described as driving the sediment yields and the latter were shown to vary strongly depending on the region (e.g Boreal climatic region $\left(6 \mathrm{t} \cdot \mathrm{km}^{-2} \cdot \mathrm{yr}^{-1}\right)$ vs. Mediterranean climatic region (218 t. $\left.\mathrm{km}^{-2} \cdot \mathrm{yr}^{-1}\right)$, lowland areas $\left(35 \mathrm{t} \cdot \mathrm{km}^{-2} \cdot \mathrm{yr}^{-1}\right.$ vs. mountainous areas $\left(204 \mathrm{t} \cdot \mathrm{km}^{-2} \cdot \mathrm{yr}^{-1}\right)$ according to Vanmaercke et al., 2011). The Louroux catchment and the sites listed in Table 1 are all characterized 
by similar climatic and topographic conditions, and they should correspond to low sedimentary production areas with median sediment yields for lowlands of $35 \mathrm{t} . \mathrm{km}^{-2} \cdot \mathrm{yr}^{-1}$ and Atlantic climate conditions of $28 \mathrm{t} \cdot \mathrm{km}^{-2} \cdot \mathrm{yr}^{-1}$ according to Vanmaercke et al (2011). However, the values measured at the outlet of these sites are much higher than expected (60-260 t. $\mathrm{km}^{-2} \cdot \mathrm{yr}^{-1}$; Table 1). Our results therefore suggest that climate and topography parameters are not the main factors controlling sediment yields in these environments.

Rather, land use and management may strongly modify landscape connectivity and are probably important factors controlling sediment yields in these flat agricultural catchments. The relative surface areas covered with cropland and grassland are shown to be an important parameter, with a much greater sediment export from catchments dominated by arable land (Bakker et al., 2008; Vanacker et al., 2005). Most of the study sites listed in Table 1 are dominated by livestock farming and their soils are therefore less exposed to erosion than catchments with a majority of arable land such as the Louroux catchment and several Belgian sites. Nevertheless, land use parameters can not fully explain the variability in sediment yields observed between the study sites listed in Table $1\left(\mathrm{r}^{2}=0.52\right)$.

Other parameters related to scale effects should be taken into account to further explain this variability. The studied catchments are rather small $\left(<26 \mathrm{~km}^{2}\right)$ and available data suggest that an increase in sediment yields with the percentage of arable land in the catchment is mainly observed in the small catchments, especially in the temperate climatic zone. At larger scales, the increase in sediment yields is compensated by the presence of buffer zones that store sediment within the catchment (e.g Cerdan et al., 2012; de Vente and Poesen, 2005; Dearing and Jones, 2003). This trend was verified for the catchments listed in Table 1. Correlation between the percentage of arable land and sediment yields is lower for catchments $>20 \mathrm{~km}^{2}\left(\mathrm{r}^{2}=0.32\right)$ compared to smaller catchments.

It appears therefore crucial to implement measures to reduce sediment connectivity between hillslopes and rivers in these flat agricultural areas located in upper parts of large river basins. Soil and water conservation measures implemented at the beginning of 2000s in similar upstream catchments of the Belgian loess belt were showed to reduce sediment delivery from $350 \mathrm{t} \mathrm{km}^{-2} \mathrm{yr}^{-1}$ to $50 \mathrm{t} \mathrm{km}^{-2} \mathrm{yr}^{-1}$ (Evrard et al., 2008). Their installation in other upstream catchments located in the European temperate zone should therefore be considered in order to limit the sediment supply to large river basins.

\section{Conclusions}

To our knowledge, this study provides one of the first quantitative reconstructions of sediment rates associated with land use and management changes during the last decades in an upstream agricultural catchment representative of similar lowland environments in Northwestern Europe. Within a few years, the sedimentary production increased dramatically, from 40 t.yr $^{-1}$ before $1950 \mathrm{AD}$ 
1 to maximum values comprised between 12000 and 14000 t.yr $^{-1}$ in the 1950 s and 1960s. Since then,

2 erosion and transfers tend to decrease regularly. However, they still reached 90 to $102 \mathrm{t}^{\mathrm{km}} \mathrm{km}^{-2} \cdot \mathrm{yr}^{-1}$

3 between 2003 and 2013, which remains 60-fold higher than before 1950.

4 This shows that soil erosion and subsequent sediment transfer to rivers may be important, even in 5 lowland environments. If our observations were confirmed in other catchments located in similar 6 environments, this would question the sustainability of the current farming practices and their 7 contribution to the degradation of the water quality. These results highlight the necessity to implement 8 soil and water conservations measures to reduce connectivity and sediment yields in lowland 9 agricultural catchments that are often wrongly considered to be low sediment production areas. 


\section{References}

Antrop, M., 2005. Why landscapes of the past are important for the future. Landscape and Urban Planning, 70, 21-34.

Ayrault, S., Le Pape, P., Evrard, O., Priadi, C.R., Quantin, C., Bonté, P., Roy-Barman, M., 2014. Remanence of lead pollution in an urban river system: a multi-scale temporal and spatial study in the Seine River basin, France. Environmental Science and Pollution Research, 21, 41344148.

Bakker, M.M., Govers, G., van Doorn, A., Quetier, F., Chouvardas, D., Rounsevell, M., 2008. The response of soil erosion and sediment export to land-use change in four areas of Europe: The importance of landscape pattern. Geomorphology, 98, 213-226.

Benoit, G., Rozan, T.F., 2001. 210Pb and 137Cs dating methods in lakes: A retrospective study. Journal of Paleolimnology, 25, 455-465.

Blaauw, M., 2010. Methods and code for a 'classical' age-modelling of radiocarbon sequences. Quaternary Geochronology, 5, 512-518.

Cerdan, O., Govers, G., Le Bissonnais, Y., Van Oost, K., Poesen, J., Saby, N., Gobin, A., Vacca, A., Quinton, J., Auerswald, K., Klik, A., Kwaad, F.J.P.M., Raclot, D., Ionita, I., Rejman, J., Rousseva, S., Muxart, T., Roxo, M.J., Dostal, T., 2010. Rates and spatial variations of soil erosion in Europe: A study based on erosion plot data. Geomorphology, 122, 167-177.

Cerdan, O., Delmas, M., Négrel, P., Mouchel, J.-M., Petelet-Giraud, E., Salvador-Blanes, S., Degan, F., 2012. Contribution of diffuse hillslope erosion to the sediment export of French rivers. Comptes Rendus Geoscience, 344, 636-645.

Chapron, E., Faïn, X., Magand, O., Charlet, L., Debret, M., Mélières, M.A., 2007. Reconstructing recent environmental changes from proglacial lake sediments in the Western Alps (Lake Blanc Huez, 2543 m a.s.1., Grandes Rousses Massif, France). Palaeogeography, Palaeoclimatology, Palaeoecology, 252, 586-600.

Chartin, C., Evrard, O., Salvador-Blanes, S., Hinschberger, F., Van Oost, K., Lefèvre, I., Daroussin, J., Macaire, J.-J., 2011. Quantifying and modelling the impact of land consolidation and field borders on soil redistribution in agricultural landscapes (1954-2009). CATENA, 110, 184-195.

Chartin, C., Evrard, O., Onda, Y., Patin, J., Lefèvre, I., Ottlé, C., Ayrault, S., Lepage, H., Bonté, P., 2013. Tracking the early dispersion of contaminated sediment along rivers draining the Fukushima radioactive pollution plume. Anthropocene, 1, 23-34.

de Boer, D.H., 1997. Changing Contributions of Suspended Sediment Sources in Small Basins Resulting from European Settlement on the Canadian Prairies. Earth Surface Processes and Landforms, 22, 623-639.

de Vente, J., Poesen, J., 2005. Predicting soil erosion and sediment yield at the basin scale: Scale issues and semi-quantitative models. Earth-Science Reviews, 71, 95-125.

Dearing, J.A., Jones, R.T., 2003. Coupling temporal and spatial dimensions of global sediment flux through lake and marine sediment records. Global and Planetary Change, 39, 147-168.

Debret, M., Sebag, D., Desmet, M., Balsam, W., Copard, Y., Mourier, B., Susperrigui, A.S., Arnaud, F., Bentaleb, I., Chapron, E., Lallier-Vergès, E., Winiarski, T., 2011. Spectrocolorimetric interpretation of sedimentary dynamics: The new "Q7/4 diagram". Earth-Science Reviews, $109,1-19$

Desmet, M., Mourier, B., Mahler, B.J., Van Metre, P.C., Roux, G., Persat, H., Lefèvre, I., Peretti, A., Chapron, E., Simonneau, A., Miège, C., Babut, M., 2012. Spatial and temporal trends in PCBs in sediment along the lower Rhône River, France. Science of The Total Environment, 433,. 189-197

Détriché, S., Rodrigues, S., Macaire, J.-J., Bonté, P., Bréhéret, J.-G., Bakyono, J.-P., Jugé, P., 2010. Caesium-137 in sandy sediments of the River Loire (France): Assessment of an alluvial island evolving over the last 50 years. Geomorphology, 115,. 11-22.

Evrard, O., Persoons, E., Vandaele, K., van Wesemael, B., 2007. Effectiveness of erosion mitigation measures to prevent muddy floods: A case study in the Belgian loam belt. Agriculture, Ecosystems \& Environment, 118, 149-158 
Evrard, O., Vandaele, K., van Wesemael, B., Bielders, C.L., 2008. A grassed waterway and earthen dams to control muddy floods from a cultivated catchment of the Belgian loess belt. Geomorphology, 100, 419-428.

Evrard, O., Van Beek, P., Gateuille, D., Pont, V., Lefèvre, I., Lansard, B., Bonté, P., 2012. Evidence of the radioactive fallout in France due to the Fukushima nuclear accident. Journal of Environmental Radioactivity, 114, 54-60.

Foster, I.D.L., Walling, D.E., 1994. Using reservoir deposits to reconstruct changing sediment yields and sources in the catchment of the Old Mill Reservoir, South Devon, UK, Over the past 50 years. hydrological Sciences, 39, $347-368$.

Foster, I.D.L., Chapman, A.S., Hodgkinson, R.M., Jones, A.R., Lees, J.A., Turner, S.E., Scott, M., 2003. Changing suspended sediment and particulate phosphorus loads and pathways in underdrained lowland agricultural catchments; Herefordshire and Worcestershire, U.K. Hydrobiologia, 494, 119-126.

Foucher, A., Salvador-Blanes, S., Vandromme, R., Cerdan, O., Desmet, M., submitted. Quantification of bank erosion in an agricultural drained catchment. Hydrological Processes.

Froger, D., Moulin, J., Servant, J., 1994. Les terres de Gatines, Boischaud-Nord, Pays-Fort, TouraineBerry. Typologie des sols. Chambres d'agriculture du Cher, de l'Indre, de l'Indre et Loire et du Loire et Cher.

Graz, Y., Di-Giovanni, C., Copard, Y., Laggoun-Défarge, F., Boussafir, M., Lallier-Vergès, E., Baillif, P., Perdereau, L., Simonneau, A., 2010. Quantitative palynofacies analysis as a new tool to study transfers of fossil organic matter in recent terrestrial environments. International Journal of Coal Geology, 84, 49-62.

Heathcote, A., Filstrup, C., Downing, J., 2013. Watershed Sediment Losses to Lakes Accelerating Despite Agricultural Soil Conservation Efforts. Plos one, 8.

I\&CLC2000, 2002. EEA-ETC/TE. 2002. CORINE land cover update. I\&CLC2000 project. Technical guidelines, http://terrestrial.eionet.eu.int.

Jacob, J., Disnar, J.-R., Boussafir, M., Sifeddine, A., Turcq, B., Spadano Albuquerque, A.L., 2004. Major environmental changes recorded by lacustrine sedimentary organic matter since the last glacial maximum near the equator (Lagoa do Caço, NE Brazil). Palaeogeography, Palaeoclimatology, Palaeoecology, 205, 183-197.

Jones, A., Panagos, P., Barcelo, S., Bouraoui, F., Bosco, C., Dewitte, O., Gardi, C., Erhard, M., Hervás, J., Hiederer, R., Jeffery, S., Lükewille, A., Marmo, L., Montanarella, L., Olazábal, C., Petersen, J., Penizek, V., Strassburger, T., Tóth, G., Van Den Eeckhaut, M., Van Liedekerke, M., Verheijen, F., Viestova, E., Yigini, Y., 2012. The state of soil in Europe (SOER). JRC $\begin{array}{llll}\text { reference } & \text { reports. } & \text { Report } & \end{array}$ http://ec.europa.eu/dgs/jrc/downloads/jrc reference report 201202 soil.pdf, 80 p.

Kiffney, P.M., Bull, J.P., 2000. Factors Controlling Periphyton Accrual during Summer in Headwater Streams of Southwestern British Columbia, Canada. Journal of Freshwater Ecology, 15, 339351.

Kummu, M., Lu, X.X., Wang, J.J., Varis, O., 2010. Basin-wide sediment trapping efficiency of emerging reservoirs along the Mekong. Geomorphology, 119, 181-197.

Libby, W.F., 1967. History of radiocarbon dating. University of Chicago Press, 22 p.

Macaire, J.-J., Bossuet, G., Choquier, A., Cocirta, C., De Luca, P., Dupis, A., Gay, I., Mathey, E., Guenet, P., 1997. Sediment Yield During Late Glacial and Holocene periods in the Lac Chambon Watershed, Massif Central, France. Earth Surface Processes and Landforms, 22, 473-489.

Macaire, J.J., Fourmont, A., Argant, J., Bréhéret, J., Hinschberger, F., Trément, F., 2010. Quantitative analysis of climate versus human impact on soil erosion since the Late-glacial: the Sarliève palaeolake catchment (France). The Holocene, 20, 497-516.

Massa, C., Bichet, V., Gauthier, E., Perren, B.B., Mathieu, O., Petit, C., Monna, F., Giraudeau, J., Losno, R., Richard, H., 2012. A 2500 year record of natural and anthropogenic soil erosion in South Greenland. Quaternary Science Reviews, 32, 119-130.

Patience, A.J., Lallier-Verges, E., Alberic, P., Desprairies, A., Tribovillard, N., 1996. Relationships between organo-mineral supply and early diagenesis in the lacustrine environment: A study of 
surficial sediments from the Lac du Bouchet (Haute Loire, France). Quaternary Science Reviews, 15, 213-221.

Rasplus, L., Macaire, J.J., Alcaydé, G., 1982. Carte géologique de Bléré au 1:5000, Editions BRGM. Reimer, P.J., Bard, E., Bayliss, A., Beck, J.W., Blackwell, P.G., Bronk Ramsey, C., Buck, C.E., Edwards, R.L., Friedrich, M., Grootes, P.M., Guilderson, T.P., Haflidason, H., Hajdas, I., Hatté, C., Heaton, T.J., Hoffmann, D.L., Hogg, A.G., Hughen, K.A., Kaiser, K.F., Kromer, B., Manning, S.W., Niu, M., Reimer, R.W., Richards, D.A., Scott, E.M., Southon, J.R., Turney, C.S.M., Van der Plicht, J., 2013. IntCal13 and Marine13 radiocarbon age calibration curves, 0-50,000 years cal BP. Radiocarbon, 55, 1869-1887.

Rein, B., Sirocko, F., 2002. In-situ reflectance spectroscopy - Analyzing techniques for high resolution pigment logging in sediment cores. Journal of Earth Sciences, 5, 950-954.

Simonneau, A., Doyen, E., Chapron, E., Millet, L., Vannière, B., Di Giovanni, C., Bossard, N., Tachikawa, K., Bard, E., Albéric, P., Desmet, M., Roux, G., Lajeunesse, P., Berger, J.F., Arnaud, F., 2013a. Holocene land-use evolution and associated soil erosion in the French Prealps inferred from Lake Paladru sediments and archaeological evidences. Journal of Archaeological Science, 40, 1636-1645.

Simonneau, A., Chapron, E., Courp, T., Tachikawa, K., Le Roux, G., Baron, S., Galop, D., Garcia, M., Di Giovanni, C., Motellica-Heino, M., Mazier, F., Foucher, A., Houet, T., Desmet, M., Bard, E., 2013b. Recent climatic and anthropogenic imprints on lacustrine systems in Pyrenean Mountains inferred from minerogenic and organic clastic supply (Vicdessos valley, Pyrenees, France). The Holocene.

Simonneau, A., Chapron, E., Garçon, M., Winiarski, T., Graz, Y., Chauvel, C., Debret, M., MotelicaHeino, M., Desmet, M., Di Giovanni, C., 2014. Tracking Holocene glacial and high-altitude alpine environments fluctuations from minerogenic and organic markers in proglacial lake sediments (Lake Blanc Huez, Western French Alps). Quaternary Science Reviews, 89, 27-43.

Sufian, A., Russell, A.R., 2013. Microstructural pore changes and energy dissipation in Gosford sandstone during pre-failure loading using X-ray CT. International Journal of Rock Mechanics and Mining Sciences, 57, 119-131.

Twichell, C., Cross, V., Hanson, A., Buck, B., Zybala, J., Rudin, M., 2005. Seismic architecture and lithofacies of turbidites in lake mead (Arizona and Nevada, U.S.A), and analogue for topographically complex basins. Journal of Sedimentary Research, 75, pp. 134 - 148.

Tyson, R.V., 1995. Sedimentary Organic Matter: Organic Facies and Palynofacies. Eds. Chapman and Hall, London., 615 pp.

van der Post, K.D., Oldfield, F., Haworth, E.Y., Crooks, P.R.J., Appleby, P.G., 1997. A record of accelerated erosion in the recent sediments of Blelham Tarn in the English Lake district. Journal of Paleolimnology, 18, 103-120.

Van Metre, P., Wilson, J., Fuller, C., Callender, E., Mahler, B., 2004. Collection, Analysis, and AgeDating of Sediment Cores From 56 U.S. Lakes and Reservoirs Sampled by the U.S. Geological Survey, 1992-2001. U.S. Geological Survey Scientific Investigations Report, 2004-5184.

Vanacker, V., Molina, A., Govers, G., Poesen, J., Dercon, G., Deckers, S., 2005. River channel response to short-term human-induced change in landscape connectivity in Andean ecosystems. Geomorphology, 72, 340-353.

Vanmaercke, M., Poesen, J., Verstraeten, G., de Vente, J., Ocakoglu, F., 2011. Sediment yield in Europe: Spatial patterns and scale dependency. Geomorphology, 130, 142-161.

Verheijen, F.G.A., Jones, R.J.A., Rickson, R.J., Smith, C.J., 2009. Tolerable versus actual soil erosion rates in Europe. Earth-Science Reviews, 94, 23-38.

Verstraeten, G., Poesen, J., 2000. Estimating trap efficiency of small reservoirs and ponds: methods and implications for the assessment of sediment yield. Progress in Physical Geography, 24, 219-251.

Verstraeten, G., Poesen, J., 2002. Using sediment deposits in small ponds to quantify sediment yield from small catchments: possibilities and limitations. Earth Surface Processes and Landforms, $27,1425-1439$.

Waters, T., 1995. Sediment in Streams Sources, Biological Effects and Control. American Fisheries Society Monograph 7. Bethesda, Maryland. 


\section{$1 \quad$ Figure captions}

2 Fig. 1: a) Location of the Louroux pond catchment in France and Europe, b) Detailed map of the 3 Louroux pond catchment (IGN - BD TOPO \& Orthophoto), c) Longitudinal topographic profile of the 4 catchment with vertical exaggeration (x25).

5 Fig. 2: a) Bathymetric map of the Louroux pond derived from an aerial LiDAR survey conducted 6 during the last drainage period (2012-2013) and location of the three sediment core, b) Delineation of 7 sedimentation areas across the pond and location of the 74 surface sediment samples collected and the 8 dredged area, c) Location of the $7.5 \mathrm{~km}$-long high resolution seismic profiles.

Fig. 3: Longitudinal (P1) and lateral (P2 and P3) seismic profiles evidencing the occurrence of homogenous sedimentation processes in the pond.

Fig. 4: Mapping of recent sediment deposition areas in the Louroux pond and results of the fuzzy kmeans classification.

Fig. 5: Description of core Lrx13-01. (A). Definition of the sedimentary units along the Lrx1301 core as derived from CT scanner images, dry bulk density, spectrocolorimetric indices plotted on a 3D diagram where the $\mathrm{Z}$ is the derivate value for the corresponding wavelength (in $\mathrm{mm}$ ) expressed by a code of color and particle size measurements (D10, D50, D90). (B). Comparison with cores Lrx12-01 and Lrx12-02 using the 570/630 spectrocolorimetric index and CT scanner images.

Fig. 6: Interpretation of the seismic wave's penetration in the units of the core Lrx13-01

Fig. 7: Sediment thickness map in Unit 1 and associated standard errors.

Fig. 8: Age depth model of core Lrx13-01 based on fallout radionuclide activities and the identification of stratigraphic markers.

Fig. 9: Evolution of pond sedimentation extrapolated from the age model derived for the last 60 years based on analysis of core Lrx13-01. The dashed line corresponds to the sediment export from the catchment hillslopes derived from the seismic data. 


\section{Table caption}

1

2

4

5

7

4

5

6

7

8

9

10

11

12

13

2 Table 1: Comparison of sediment yields in small $\left(<100 \mathrm{~km}^{2}\right)$ agricultural catchments of Western 3 Europe. 


\section{Acknowledgements}

1

2 advices and technical support. This study was financially supported by the Agence de l'Eau Loire Bretagne (Loire-Brittany Water Agency). 
Fig. 1
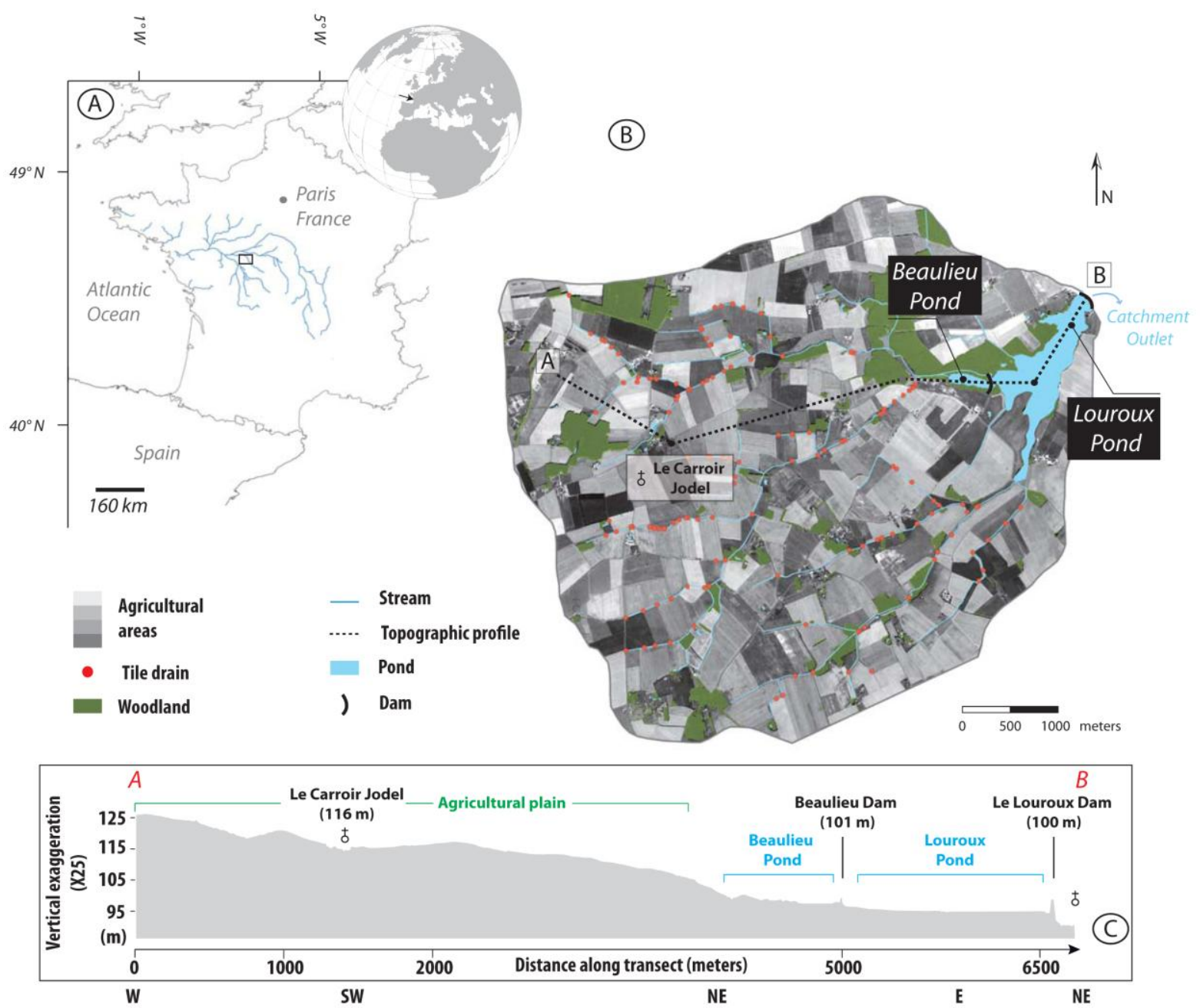
Fig. 2

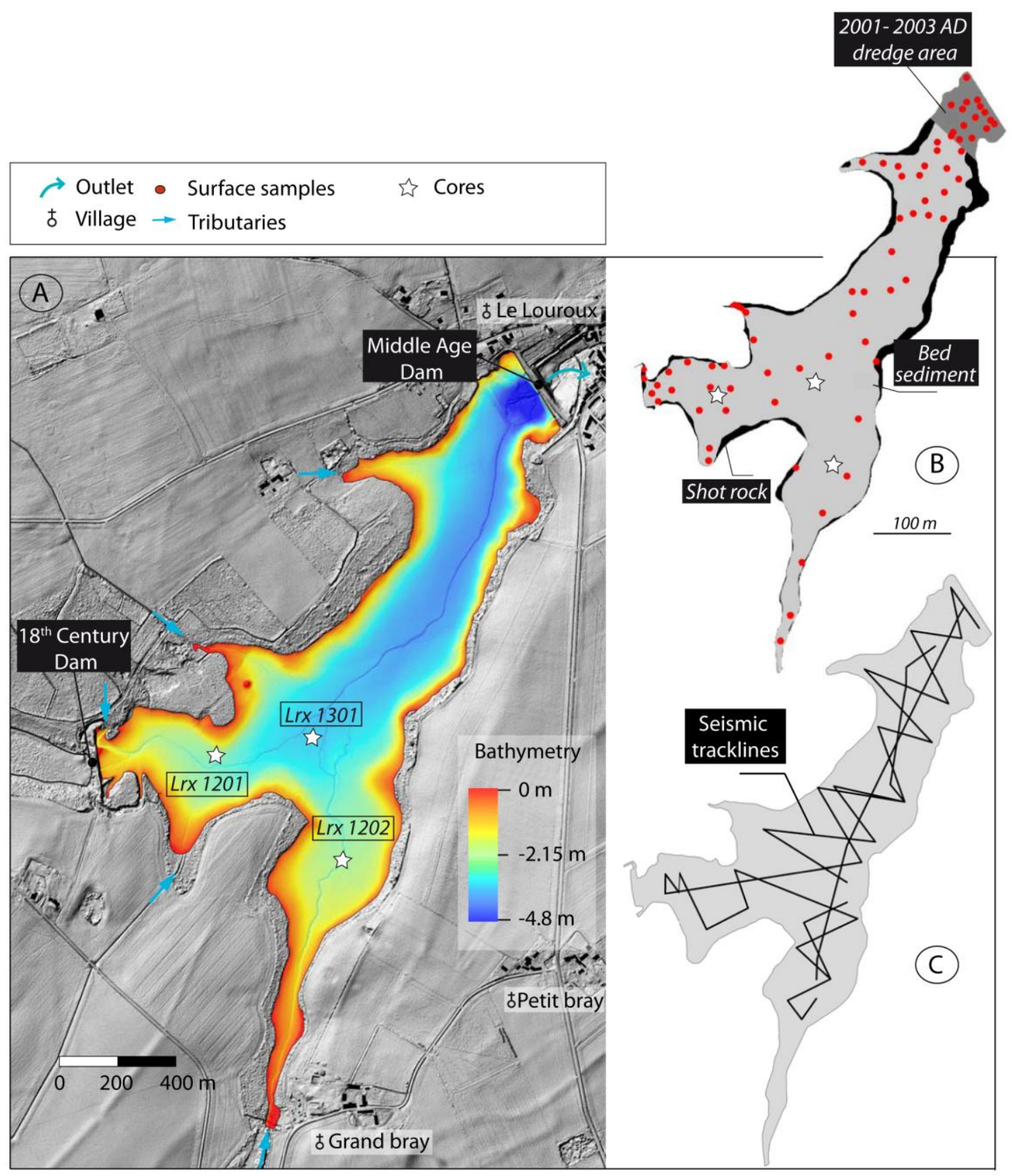


Fig. 3

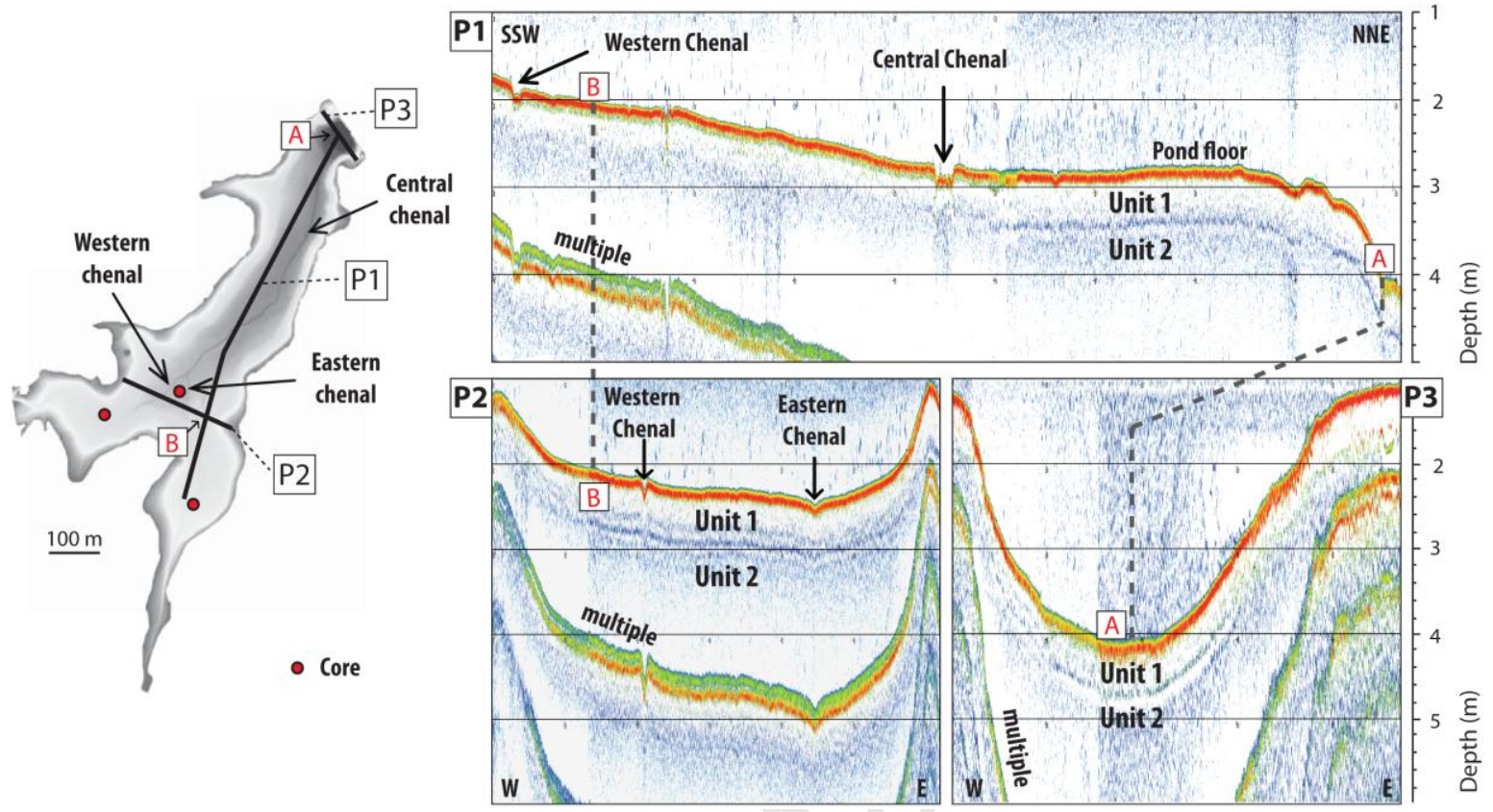


Fig. 4

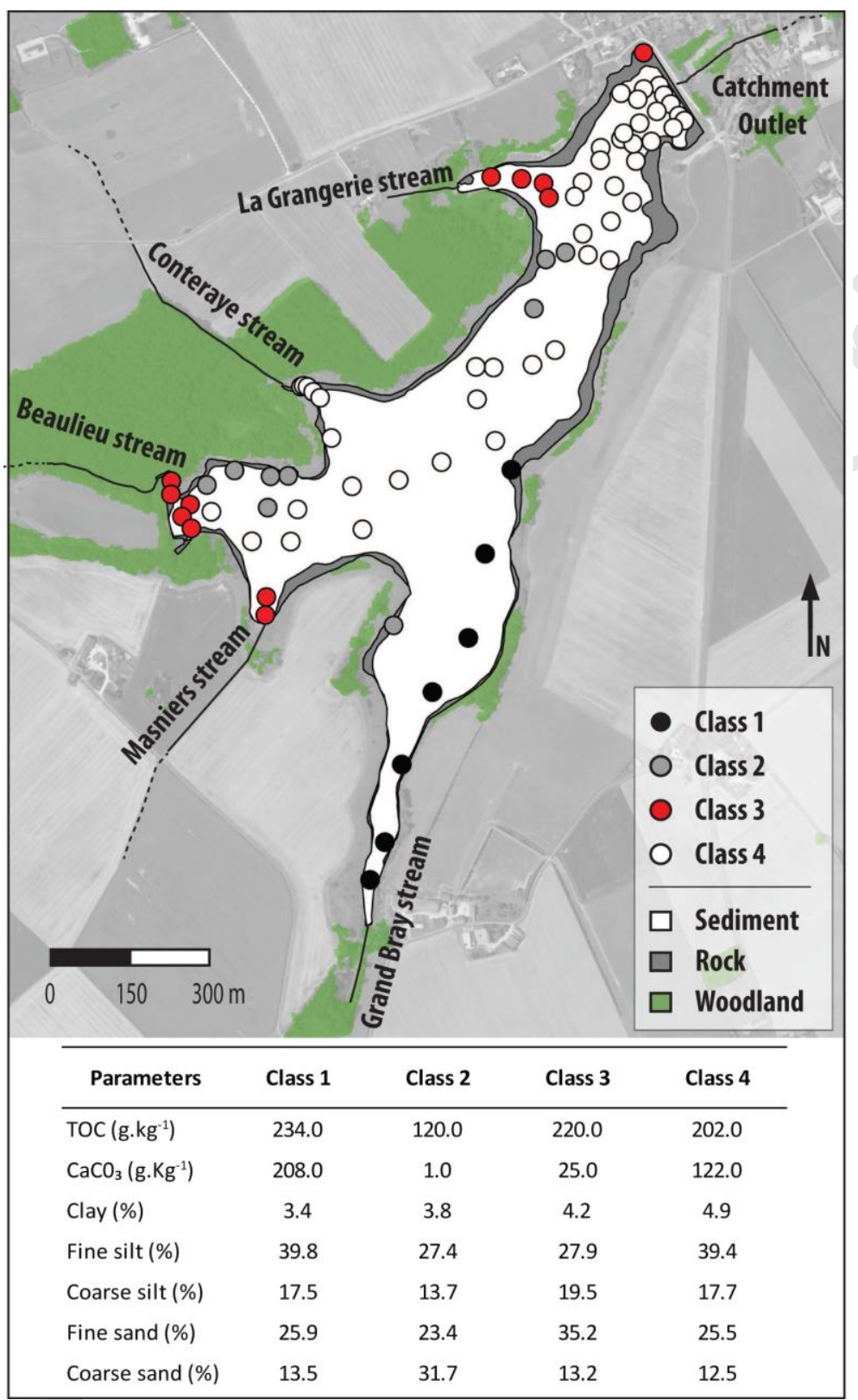


Fig. 5

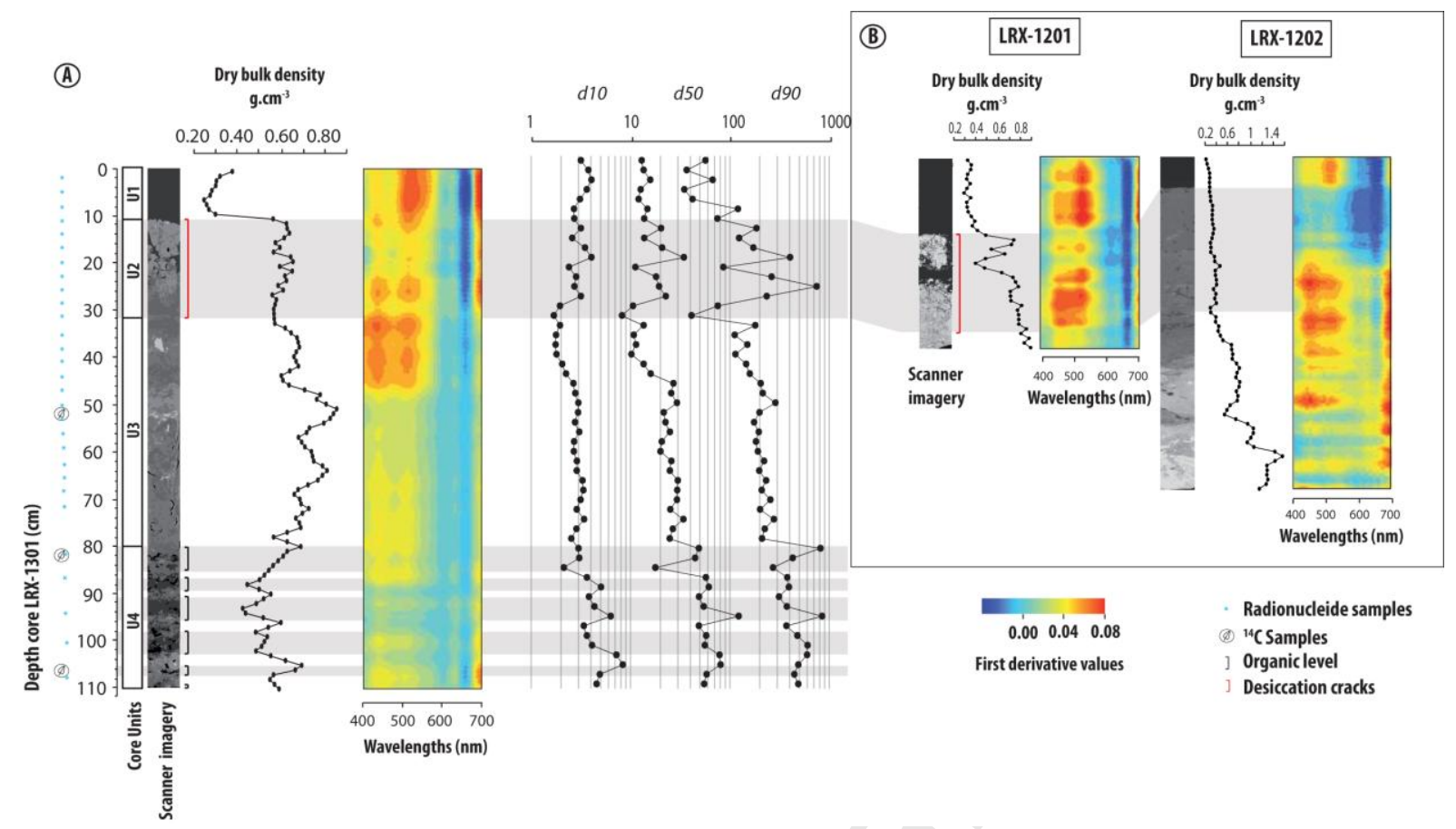


Fig. 6

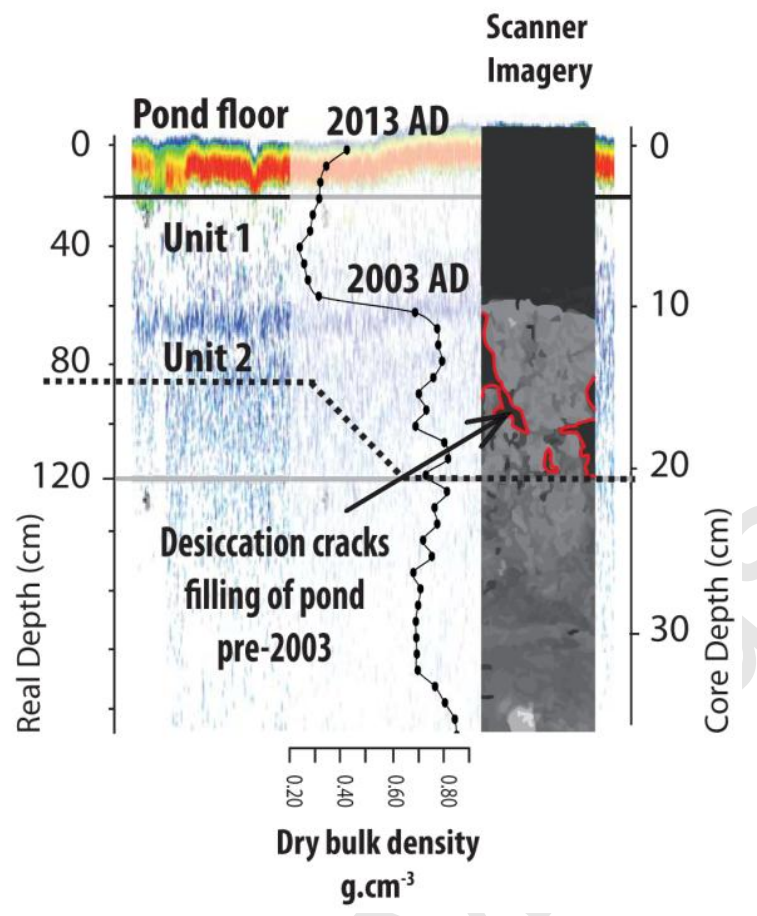


Fig. 7
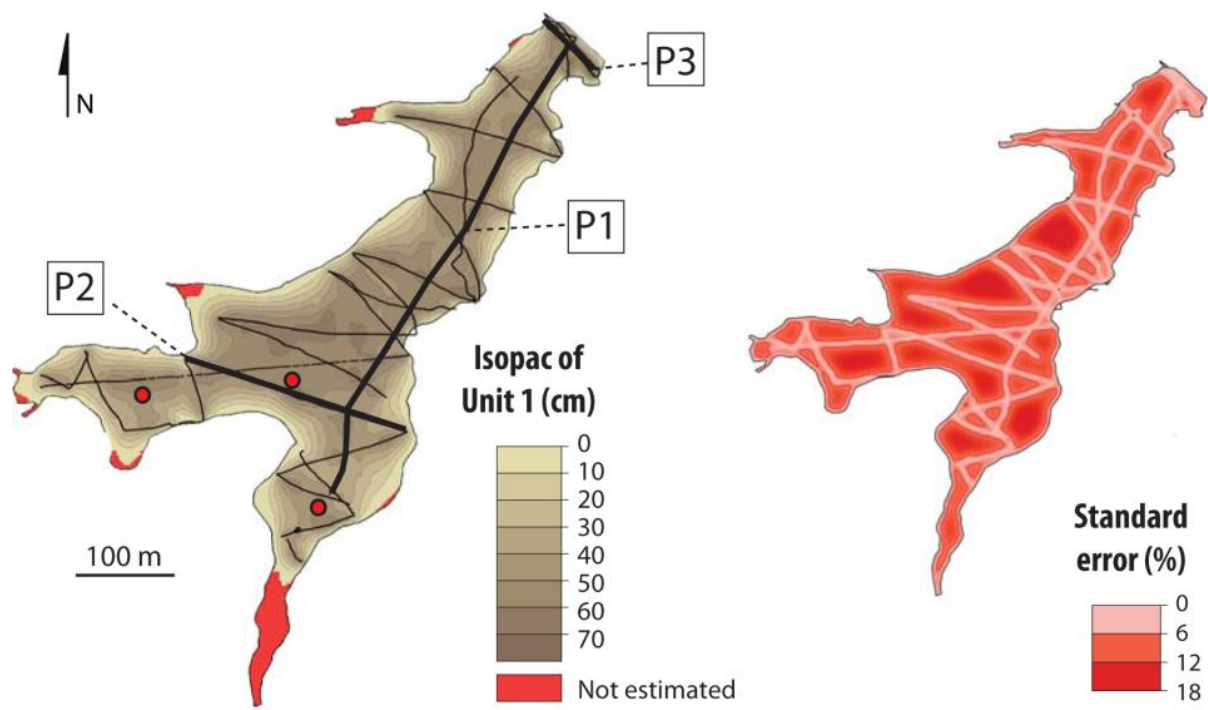
Fig. 8

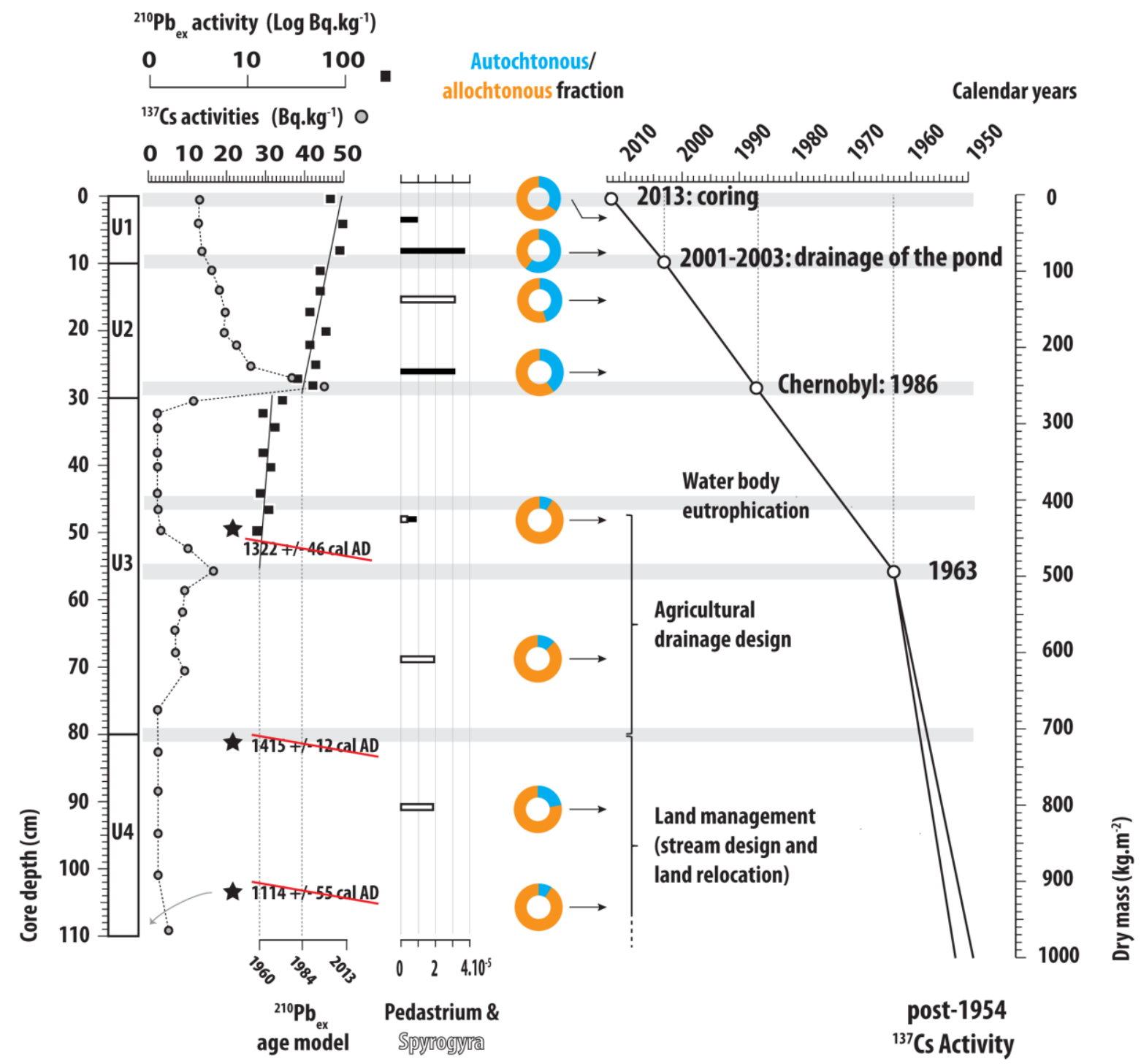


Fig. 9

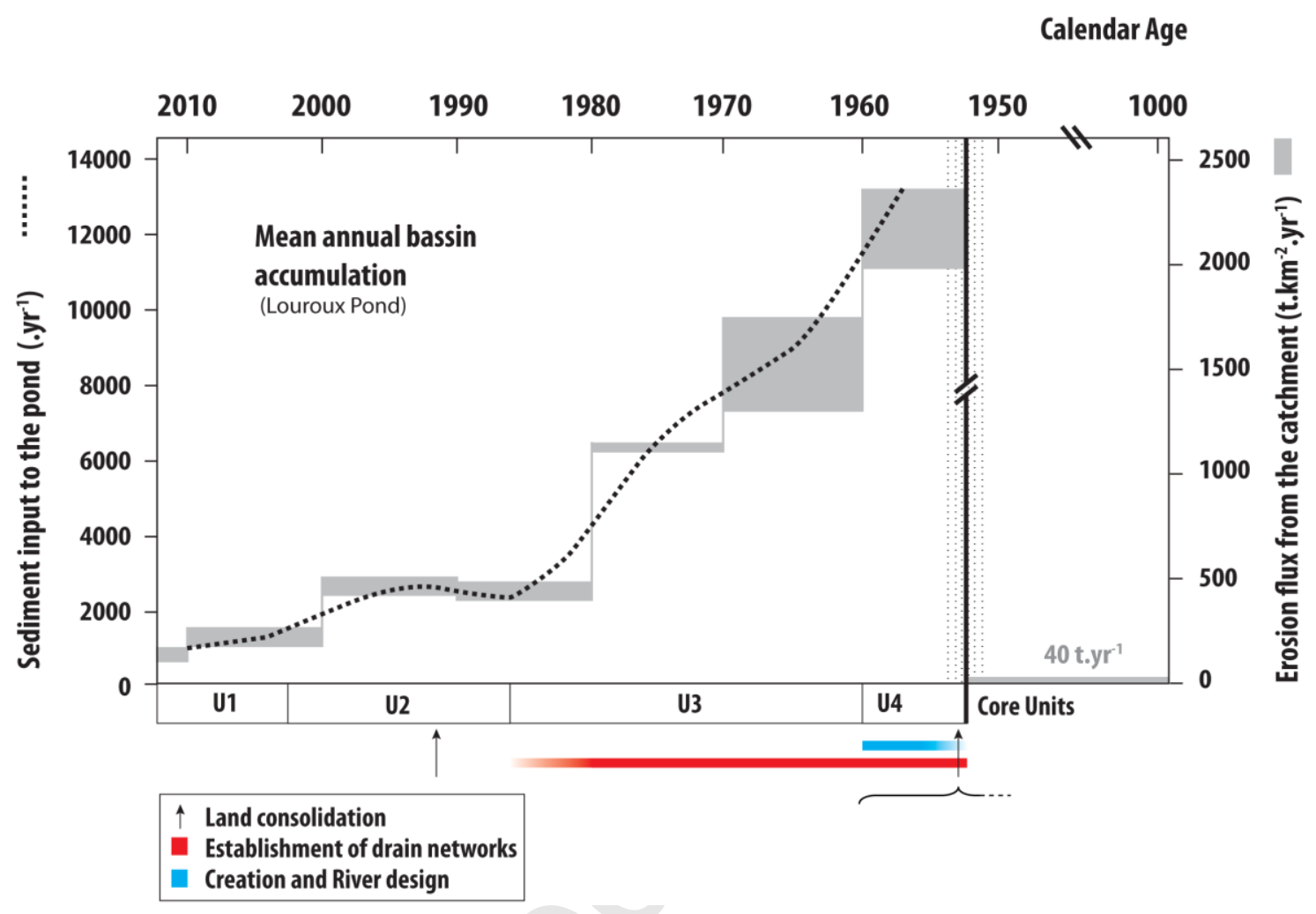




\begin{tabular}{|c|c|c|c|c|c|c|}
\hline Catchment/country & $\begin{array}{c}\text { Gauging } \\
\text { station } \\
(\mathrm{GS}) / \text { reservoir }\end{array}$ & $\begin{array}{l}\text { Area } \\
\left(\mathrm{km}^{2}\right)\end{array}$ & $\begin{array}{c}\mathrm{SY} \\
\left(\mathrm{t} . \mathrm{km}^{2} \cdot \mathrm{yr}-\right. \\
1)\end{array}$ & $\begin{array}{l}\text { Min/Max } \\
\text { elevation - } \\
\text { slope }\end{array}$ & $\begin{array}{l}\% \text { of arable } \\
\text { land }\end{array}$ & Source \\
\hline $\begin{array}{l}\text { Rosemaud catchment } \\
\text { (UK) }\end{array}$ & Gs & 1,5 & $\begin{array}{l}80.2- \\
83.7\end{array}$ & $76-115 \mathrm{~m}$ & 62 & Walling et al., 2002 \\
\hline $\begin{array}{l}\text { Old mild reservoir } \\
\qquad(\mathrm{UK})\end{array}$ & $\mathrm{R}$ & 1,6 & 90 & $53-194 m$ & 20 & Foster et al., 1994 \\
\hline $\begin{array}{c}\text { Kyre pool catchment } \\
\text { (UK) }\end{array}$ & $\mathrm{R}$ & 3 & 90 & $90-262 \mathrm{~m}$ & 18 & Foster et al., 2003 \\
\hline Le Moulinet (Fr) & Gs & 5 & 63 & $55-134 \mathrm{~m}$ & 50 & Vongvixay et al., 2012 \\
\hline Kemmelbeek (Bel) & $\mathrm{R}$ & 11 & 260 & $24-135 \mathrm{~m}$ & 91 & $\begin{array}{l}\text { Verstraeten and Poesen, } \\
2001\end{array}$ \\
\hline Rooigembeek (Bel) & $\mathrm{R}$ & 14 & 230 & $21-73 m$ & 90 & $\begin{array}{l}\text { Verstraeten and Poesen, } \\
2001\end{array}$ \\
\hline Zwedebeek (Bel) & $\mathrm{R}$ & 14 & 150 & $31-64 m$ & 83 & $\begin{array}{l}\text { Verstraeten and Poesen, } \\
2001\end{array}$ \\
\hline Steenbeek (Bel) & $\mathrm{R}$ & 19 & 160 & $5-41 m$ & 79 & $\begin{array}{l}\text { Verstraeten and Poesen, } \\
2001\end{array}$ \\
\hline Le Louroux $(F r)$ & $R$ & 24 & $90-102$ & $99-127 m$ & 76 & This study \\
\hline Broenbeek (Bel) & Gs & 25 & 60 & $8-49 m$ & 89 & $\begin{array}{l}\text { Verstraeten and Poesen, } \\
2001\end{array}$ \\
\hline Douvebeek (Bel) & Gs & 26 & 210 & $28-152 \mathrm{~m}$ & 95 & $\begin{array}{l}\text { Verstraeten and Poesen, } \\
2001\end{array}$ \\
\hline
\end{tabular}

